\title{
Author: S Woolman
}

BETWEEN NORMS AND FACTS: THE CONaSTITUTIONAL COURT'S COMMITMENT TO PLURALISM IN SOUTH AFRICA'S RADICALLY HETEROGENEOUS PUBLIC SCHOOLS

\section{eISSN 1727-3781}

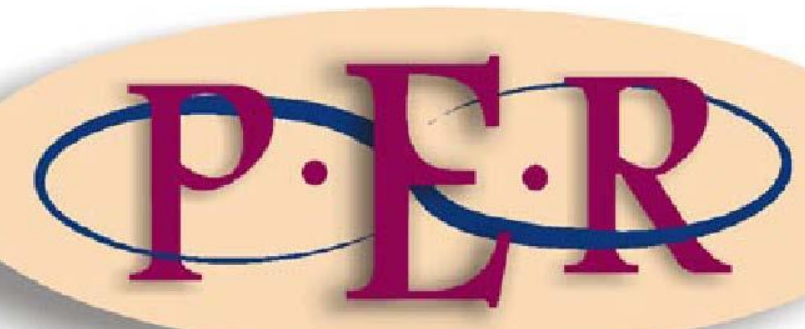

2015 VOLUME 18 No 6 


\section{BETWEEN NORMS AND FACTS:}

\section{THE CONSTITUTIONAL COURT'S COMMITMENT TO PLURALISM \\ IN SOUTH AFRICA'S RADICALLY HETEROGENEOUS PUBLIC SCHOOLS}

\section{S Woolman*}

The concept of practical reason as a subjective capacity is of modern vintage. Converting the Aristotelian conceptual framework ... had the advantage ... of relating practical reason to the "private" happiness and "moral" autonomy of the individual. $[P]$ ractical reason was thenceforth related to the freedom of the human being as private subject who could assume the roles of member of civil society and citizen, both national and global. ... Hegel remained convinced, just like Aristotle, that society finds its unity in the political life and organisation of the state. ... However, modern societies have since become so complex that these two conceptual motifs - that of a society concentrated in the state and that of society made up of individuals - can no longer be applied unproblematically. ... [I]n the Marxist concept of a democratically self-governing society ... both the bureaucratic state and the capitalist economy were [largely] supposed to disappear. Systems theory erases even these traces. The state forms just one subsystem alongside other functionally specified social subsystems. $2 \ldots$ The development of constitutional democracy along the celebrated 'North Atlantic' path has certainly provided us with results worth preserving, but once those who do not have the good fortune to be the heirs of the Founding Fathers turn to their own traditions, they cannot find criteria and reasons that would allow them to distinguish what would be worth preserving from what should be rejected.

\section{Introduction}

Law is a terribly derivative discipline. That proposition shouldn't surprise most readers. Law serves many masters: economics (privilege and class structures); politics (maintaining and disrupting the status quo); epistemology (belief in cold, hard facts or subjectivism); religion (for some, as its prior, moral underpinning; for others, a sacred domain that ought to remain distinct from the profane); language and culture (the contention that a nation must reflect the traditions of a relatively homogeneous volk), and even metaphysics (some who believe that all persons are causally free to do as they wish, and others who contend that the various communities into which we are born largely determine how we go about pursuing a life worth valuing.) Oh, and let me not forget the social contract tradition that stretches from Locke to Rawls to our own Constitution: that the law secures its

Stuart Woolman BA, Honors (Wesleyan) MA (Columbia) JD (Columbia Law) PhD (Pretoria) Professor of Law and Elizabeth Bradley Chair of Ethics, Governance and Sustainable Development; Editor-in-Chief, Constitutional Law of South Africa; Editor-in-Chief, Constitutional Court Review. 
legitimacy only through the consent of the governed. It should come as little surprise that the relatively small cluster of education-related decisions handed down by our Constitutional Court serve these many masters. But, as we pull back and view the jurisprudence in Habermasian terms, one dominant theme jumps out: pluralism. Habermas identifies pluralism as the central problem for most of the post-1990 constitutional democracies that arose out of authoritarian regimes. The disjunction between the lofty norms articulated in our basic law and the panoply of South African ethical, cultural, linguistic and cultural traditions is especially picante in the field of education law and policy.

Put slightly differently, we are engaged in what Habermas believes to be the most challenging of projects - the unification of multiple legal, moral, ethical, cultural, social, moral and political traditions, in a highly stratified economy with the highest Gini coefficient in the world, with little history of trust between peoples from dramatically different communities, under the banner of a single state fashioned in terms of a basic law to which all other norms or forms of law are, putatively, subsidiary. That's a really big ask. ${ }^{1}$ It therefore seems worth acknowledging (a) that 20 years constitutes a mere blip in time; (b) that the stitching together of multiple societies (whose individual members (i) speak at least one of the 11 official

1 See Judt 'Is there a Belgium?' (December 1999) The New York Review of Books 10. Belgium has 10 million inhabitants, and enjoys the honour of being host to the legislative, regulatory and administrative apparatus of the European Union. Yet it doesn't operate in a manner that we would associate with a modern European state. It's not simply that the Dutch-speaking Flemings and the French-speaking Walloons have never mastered the fine art of bi-cultural cohabitation. (They are now split into two unilingual units.) Judt's account reveals how each little town, or tourist destination, or metropolis functions rather autonomously through archaic patrimonial 'pillars' dispersed into five regions in Flanders and five regions in Wallonia. Local power arrangements embedded in distinct unilingual regions makes meaningful national coordination difficult and governance fundamentally corrupt and undemocratic. Belgium looks more like a loose affiliation of postal codes, than the country that inspired Conrad's Heart of Darkness. As Judt observes:'Belgium has much to commend it beyond the self-deprecatingly touted virtues of beer and waffles; but its most salient quality today may be the illustration that this country can furnish of the perils now facing states everywhere.' Id. Also see Judt Postwar: A history of Europe since 1945 (2005). Belgium seemingly lacks the capacity to address urgent systemic challenges through collective action. Judt thus partially reverses the spin of Habermas' observation regarding new democracies. He tenders an Orwellian sense of how established democracies can corrode quite quickly into divisively distinct and dangerous cantons. See further Judt 'On intellectuals and democracy'(May 2012) The New York Review of Books 5 ('They corrode because most people don't care very much about them ... The difficulty of sustaining voluntary interest in the business of choosing the people who will rule over you is well attested.') By 2012, Judt had further evidence that political parties had the capacity to render modern multiparty democracies ungovernable to the point of failure or collapse. See Plattner 'Is democracy in decline?' (2015) 26 Journal of Democracy 1, 8-10. 
languages, and (ii) operate on a daily basis according to far more numerous and complex visions of the good) requires a significant amount of heavy lifting, and (c) that the basic law, even with all the laws and judgments designed to give it effect, cannot rectify all the wrongs of the past nor provide all the material and immaterial goods learners require in order to pursue lives worth valuing.

But this article does not focus on the degree to which our nascent democracy has succeeded or failed to meet the lofty aspirations of our Constitution. It has a far more narrow focus. It suggests, and hopefully shows, that the Constitutional Court has achieved something rather remarkable in its education jurisprudence. In addressing concerns about what constitutions in non-North Atlantic democracies can do, it has crafted a body of law that recognises the plurality of traditions to which our education law must speak. In so doing, it has identified a golden thread that ties all of its education judgments together: a commitment to pluralism that opens all school doors to all learners and attempts to start us down the long, arduous path of learning to live with one another.

This article takes the following form. Section 2 sets out the relevant extant constitutional doctrine on learners' rights. Section 3 reveals the delicate doctrinal thread of pluralism that runs through the Constitutional Court's judgments and assesses the manner in which it has transformed, quite modestly, the nature of tuition in our heterogeneous classrooms.

\section{Learners' rights and doctrinal analysis}

\section{1 "On your own dime": The difference between maintaining cultures, languages and religions in public schools as against private schools}

Section 29(3) of the Constitution permits linguistically and culturally restrictive admissions policies at independent schools so long as these policies do not discriminate, intentionally, upon the basis of race. The Constitutional Court, in Gauteng School Education Bill, made it quite clear that comprehensive visions of the good are more 
appropriately accommodated in private schools and not in our public schools. ${ }^{2}$ As Kriegler J notes in Gauteng School Education Bill, s 32(c) of the Interim Constitution (now s 29(3) of the Constitution) and then extant national and provincial education legislation collectively constitute

a bulwark against the swamping of any minority's common culture, language or religion. For as long as a minority actually guards its common heritage, for so long will it be its inalienable right to establish educational institutions for the preservation of its culture, language or religion ... There are, however, two important qualifications. Firstly ... there must be no discrimination on the ground of race ... The Constitution protects diversity, not racial discrimination. Secondly... [the Constitution] ... keeps the door open for those for whom the State's educational institutions are considered inadequate as far as common culture, language or religion is concerned. They are at liberty harmoniously to preserve the heritage of their fathers for their children. But there is a price, namely that such a population group will have to dig into its own pocket. ${ }^{3}$

While sympathetic to the belief that communities bound by common culture, language or religion are an important source of meaning for most South Africans, Justice Kriegler makes it clear that the post-apartheid state can no longer support public institutions that privilege one way of being in the world over another. The Constitution's answer to those parents who wish to school their children in the language, culture or religion of their choice is pretty straightforward: you may "dig into your own pocket" and build the "independent school" on your own time. ${ }^{4}$

\section{2 'Spare the Rod': Discipline in faith-based Independent Schools}

In Christian Education South Africa v Minister of Education, the Constitutional Court was seized with the question as to whether or not corporal punishment in a private faithbased school could be used as a method of discipline. ${ }^{5} S v$ Williams had held that

2 See Ex parte Gauteng Provincial Legislature: In Re Dispute Concerning the Constitutionality of Certain Provisions of the Gauteng School Education Bill of 199519963 SA 165 (CC), 19964 BCLR 537 (CC) (Justice Sachs argues that the religious, linguistic and cultural rights found in the Interim Constitution are best understood as efforts to "concretise ... a certain measure of cultural/linguistic autonomy in the private sphere. ... Section 32(c) appears... to be an explicit, if limited, acknowledgement of the need in certain circumstances to allow for a departure from the general principles of [non-discrimination] ... What appears to be provided for ... is not a duty on the State to support discrimination, but a right of people ... to further their own distinctive interests.")

3 Id paras 39-42. Also see Woolman \& Fleisch The Constitution in the Classroom: Education and the Law in South Africa, 1994 - 2008 (2009).

4 Woolman "Defending discrimination: On the constitutionality of independent schools that promote a partial, if not a comprehensive, vision of the good" (2007) Stellenbosch Law Review 31.

520004 SA 757 (CC), 200010 BCLR 1051 (CC). 
court-imposed whipping impairs the right to dignity of minors. ${ }^{6}$ The Christian Education Court extended the line of reasoning in Williams and held that although the applicants had correctly averred that the prevention of corporal punishment in faith-based independent schools was a prima facie infringement of their rights to religious freedom (s 15) and religious practice (s 31), the infringements were both reasonable and justifiable.

The judgment contains valuable language about how our equality jurisprudence tolerates legal and cultural asymmetries. The essence of equality under the South African Constitution, so says the judgment, is that it does not require that we treat everyone the same way, but that we treat everyone with equal concern and respect. ${ }^{7}$ And that's just a fancy way of saying that we need not all act the same way in order to enjoy the benefits - ie, religious, cultural, ethnic and associational - vouchsafed by a liberal constitution.

The Christian Education Court, however, does not extend the benefit of this understanding of equality to the use of corporal punishment in religious or faith-based independent schools. A commitment to pluralism does mean that "anything goes". The judgment assumes that for the purposes of analysing the constitutionality of $s 10$ of the South African Schools Act $^{8}$ - which bars the use of corporal punishment by teachers ss 15 and 31 of the Constitution have been infringed. Upon moving to the limitations analysis under s 36, the Christian Education Court explains why the state is justified in barring corporal punishment in religious independents schools and why the court will not craft an exemption for such punishment.

Some readers might view this outcome as inconsistent with overcoming the Habermasian problem. That conclusion would be far too hasty. In our new pluralist order, it is perfectly reasonable to override religious dictates and to bar the corporal punishment of children in schools of any kind. First, corporal punishment impairs a child's right to dignity in terms of $s 10$ of the Constitution. Second, it reflects an invasion of bodily integrity in terms of the right to freedom and security of the person in terms of

19953 SA 632(CC), 19957 BCLR (CC).

Id para 42.

Act 84 of 1996. 
s 12 of the Constitution. Third, by allowing teachers (known personally to students) to mete out punishment, it manifestly breaches a child's right in terms of s 28(1)(d) of the Constitution "to be protected from maltreatment, neglect, abuse or degradation". Finally, children are in no position to determine the desirability of a set of religious practices that may result in harm to themselves.

A constitutional commitment to pluralism only requires that we take other "ways of being in the world" seriously. ${ }^{9}$ An appreciation of our differences - raised by Justice Sachs to the level of a constitutional value - could not possibly entitle us to do whatever we like. That connotation would invite chaos: and that's what any system of law, by definition, is designed to prevent. In addition, rights often conflict with one another. As citizens, or as petitioners before a court, or as judges, we must first discern what our Constitution requires of us and then, secondly, decide which religious, cultural, ethnic, traditional or social practices are consistent with those requirements, and which must go. (But let's recall our Habermasian insight: given our radical heterogeneity, we will not always possess an uncontroversial explanation for what the Constitution requires of us.) If a problem exists with the Christian Education Court's distinction, then it turns on the Court's distinction between the practice of religion in schools and the practice of religion elsewhere, i.e., the home. If children lack the capacity to decide for themselves whether or not religious practices will prove deleterious to their health - and it therefore becomes incumbent upon the state to intervene on their behalf - then it would seem reasonable to conclude that barring religion-sanctioned corporal punishment at home should be no different from barring religion-sanctioned corporal punishment at school. But that is not what the Court concludes. Instead, it inclines toward the proposition that parents "were not being obliged to make an absolute and strenuous choice between obeying a law of the land or following their conscience. They could do both simultaneously." ${ }^{10}$ Parents can follow their conscience at home. However, they must still obey the law of the land by having their children attend school free from corporal punishment. Can the Christian Education Court have it both ways? At first blush, it would appear that either (a) the scope for religious autonomy and the religious

\footnotetext{
9 Prince $v$ President, Cape Law Society 20022 SA 794 (CC), 20021 SACR 431 (CC), 20023 BCLR 231 (CC).

10 Christian Education (n 5) para 51.
} 
community's constitutive attachments is sufficient to justify corporal punishment in school and at home, or (b) a child's right to dignity is of such paramount importance for the state to bar it when deployed at school or at home. ${ }^{11}$

\section{The legislature has provided a fairly definitive answer to the Christian Education Court's} conundrum. The Children's Act, s 12, promulgated in 2005, states that "every child has

the right not to be subjected to social, cultural or religious practices which are detrimental to his or her well-being."12

11 Woolman and Bishop "Education" in Woolman \& Bishop (eds) Constitutional law of South Africa (2 ${ }^{\text {nd }}$ Edition, 2008) Chapter 58.

12 Act 38 of 2005. Hard cases elicit different responses from our highest court. In Prince, Justice Sachs articulates his initial understanding of a "right to be different". In demanding that his colleagues, the state and his fellow citizens "walk the extra mile" when it comes to marginal subpublics, Sachs writes: "Intolerance may come in many forms. At its most spectacular and destructive it involves the use of power to crush beliefs and practices considered alien and threatening. At its more benign it may operate through a set of rigid mainstream norms which do not permit the possibility of alternative forms of conduct." Prince $v$ President, Cape Law Society 20022 SA 794 (CC), 20021 SACR 431 (CC), 20023 BCLR 231 (CC) para 145 (Court holds that the Rastafarian use of cannabis in religious rituals is justifiably impaired by criminal sanctions because the legislature has the power prohibit conduct it considers to be anti-social.) Sachs comes close to accusing his of being in the grip of a blinkered hypocrisy. He writes: "In Christian Education, this Court held that a number of provisions in the Constitution affirmed the right of people to be who they [are] without being forced to subordinate themselves to the cultural and religious norms of others, and highlighted the importance of individuals and communities being able to enjoy what has been called the 'right to be different'. In each case, space [had] been found for members of communities [in our democracy] to depart from a general norm." Id paras 170-172. Democracy in a society of radically heterogeneous communities, Sachs argues, presupposes the capability of marginalised and vulnerable minorities to challenge the normative closure into which political communities tend to lapse. A society can remain free only if it values plurality, and allows out-groups to challenge deeply held majoritarian beliefs and practices. For this reason, the critical challenge for our constitutional "democracy" consists "not in accepting what is familiar and easily accommodated, but in giving reasonable space to what is 'unusual, bizarre or even threatening'". Id para 71. In Bhe, another dissent challenges the flattening of our diverse subpublics in the name of core constitutional values. In Bhe v Magistrate, Khayelitsha 20051 SA 580 (CC), 20051 BCLR 1 (CC). Justice Ngcobo writes:

Ours is not the only country that has a pluralist legal system in the sense of common, statutory and indigenous law. Other African countries that face the same problem have opted not for replacing indigenous law with common law or statutory laws. Instead, they have accepted that indigenous law is part of their laws and have sought to regulate the circumstances where it is applicable. In my view this approach reflects recognition of the constitutional right of those communities that live by and are governed by indigenous law. ... It is a recognition of our diversity, which is an important feature of our constitutional democracy. [I]n accommodating different systems of law in order to ensure that the most vulnerable are treated fairly ... [t] he choice of law mechanism must be informed by the need to: (a) respect the right of communities to observe cultures and customs which they hold dear; (b) preserve indigenous law subject to the Constitution; and (c) protect vulnerable members of the family. Id paras $235-238$.

The Fourie Court captures much of what is at stake in matters in which traditional forms of private ordering and the novel social formations apparently required by our basic law are at odds:

A democratic, universalistic, caring and aspirationally egalitarian society embraces everyone and accepts people for who they are. At the very least, it affirms that difference should not be the basis for exclusion, marginalisation and stigma. ... The acknowledgment and acceptance of difference is 
Whether or not a child receives an education at a religiously-inflected public school, a faith-based independent school, or at home according to religious dictates, the best interests of the child remain paramount and preclude the use of corporal punishment to maintain order. If, however, we wish to recognise Christian Education as a victory for pluralism, then a more charitable reading must be offered. Having previously addressed corporal punishment in public schools in Williams, the Christian Education Court extends its reasoning to corporal punishment in private schools. Whether home-schooling would be subject to the same dictates and a comparable outcome was not placed before the Court. Courts - especially apex courts - must do more than simply adjudicate one case at a time. ${ }^{13}$ But we should not expect such courts to provide a theory of everything in every decision. The trajectory of the Christian Education Court's reasoning is clear enough. Moreover, should they ever be asked to engage discipline and homeschooling, their own judgments, the countervailing rights in the Constitution and Children's Act provide a relatively clear answer as to what the Court would and should decide when the Court is seized with such a matter.

particularly important in our country where for centuries group membership based on supposed biological characteristics such as skin colour has been the express basis of advantage and disadvantage. South Africans come in all shapes and sizes. The development of an active rather than a purely formal sense of enjoying a common citizenship depends on recognising and accepting people with all their differences, as they are. The Constitution thus acknowledges the variability of human beings ...., affirms the right to be different, and celebrates the diversity of the nation. Accordingly, what is at stake is not simply a question of removing an injustice experienced by a particular section of the community. At issue is a need to affirm the very character of our society as one based on tolerance and mutual respect. The test of tolerance is not how one finds space for people with whom, and practices with which, one feels comfortable, but how one accommodates the expression of what is discomfiting.

Minister of Home Affairs v Fourie 20061 SA 524 (CC), 20063 BCLR 355 (CC) para 61. Prince, Bhe and Fourie reflect the tension between the many South African subpublics governed by different normative frameworks, and Pharmaceutical Manufacturer's assertion that the Constitution gives all normative frameworks their force. 


\subsection{The space for cultural autonomy}

In KwaZulu-Natal MEC for Education v Pillay, the Constitutional Court had to decide if a Hindu learner was entitled to wear a nose stud to school as an expression of her Tamil culture and Hindu religion. ${ }^{14}$ The school had refused to permit her to wear the stud on the grounds that the wearing of the stud did not fall within the core belief set of the religion. The Constitutional Court held that the "norm embodied by the Code is not neutral, but enforces mainstream and historically privileged forms of adornment, such as ear studs which also involve the piercing of a body part, at the expense of minority and historically excluded forms". Chief Justice Langa found, in addition, that voluntary religious and cultural practices were entitled to the same protection as obligatory practices. While recognising the importance of codes of conduct and the need to ensure discipline, Chief Justice Langa concluded that a mere appeal to uniformity was insufficient grounds to refuse a learner's request for an exemption from a code:

[I]f there are other learners who hitherto were afraid to express their religions or cultures and who will now be encouraged to do so, that is something to be celebrated, not feared. As a general rule, the more learners feel free to express their religions and cultures in school, the closer we will come to the society envisaged in the Constitution. The display of religion and culture in public is not a "parade of horribles" but a pageant of diversity which will enrich our schools and in turn our country. ${ }^{15}$

A school that wishes to enforce a code of conduct under the kind of circumstances that brought Ms Pillay to court will have to show that a particular exemption is more likely than not to cause a palpable disruption to school activities. Given the absence of any such evidence, the Court found that the learner ought to have been granted an exemption. ${ }^{16}$

2007 ZACC 21, 20081 SA 474 (CC), 20082 BCLR 99 (CC).

Id para 107.

In Antonie v Governing Body, Settlers High School, a learner had been found guilty of "serious misconduct" for attending school with dreadlocks and a cap she deemed to be essential parts of the practice of her Rastafarian faith. 20024 SA 738 (C). In the High Court, Van Zyl J held that codes of conduct should not be rigidly enforced. They must instead be read in "a spirit of mutual respect, reconciliation and tolerance. The mutual respect, in turn, must be directed at understanding and protecting, rather than rejecting and infringing, the inherent dignity, convictions and traditions of the offender". Id para 17. The student's conduct was ultimately held to fall well short of the definition of "serious misconduct", and the High Court set aside the School Governing Body's decision. 
But what of a school that wishes to order itself and its students along cultural and linguistic lines? Here, we have seen the Court offer far less solicitude to singlemedium public schools. After a long line of High Court cases, ${ }^{17}$ the Constitutional Court in Ermelo makes it clear that considerations of equality and transformation will, more often than not, trump considerations of cultural and linguistic solidarity asserted by the School Governing Bodies of primary and secondary public schools. Put slightly differently, s 29(2) of the Constitution eliminates any "right" to singlemedium public schools, grants the state ultimate authority over language policy and makes any demand for single-medium schools subject to threshold tests for equity, practicability and historical redress. ${ }^{18}$ Although Ermelo addresses itself to a mixed bag of legal irregularities, opaque statutory provisions and complex constitutional issues, it's the Court's commitment to pluralism that animates the decision to the transform a single-medium school into a dual-medium school. ${ }^{19}$ However, Deputy

17 Matukane v Laerskool Potgietersrus 1996 (3) SA 223 (T); Laerskool Middelburg v Departementshoof, Mpumalanga Departement van Onderwys 20034 SA 160 (T); Governing Body, Mikro Primary School v Minister of Education, Western Cape 20053 SA 504 (C), 20052 All SA 37 (C), 200510 BCLR 973 (C); Seodin Primary School v MEC Education, Northern Cape 20061 All SA 154 (NC). The Supreme Court of Appeal's decision in Mikro must be seen both as an outlier, and overturned as a matter of law by Ermelo.

18 Head of Department, Mpumalanga Department of Education v Hoërskool Ermelo 20102 SA 415 (CC), 20103 BCLR 177 (CC). The Constitutional Court held that the same set of propositions hold true for 'right to a basic education' analysis in terms of s 29(1) of the Constitution. Also see Member of the Executive Council for Education in Gauteng Province $v$ Governing Body of the Rivonia Primary School 2013 ZACC 34 paras 36, 39, 44, 48, 49:

The Schools Act envisages that public schools are run by a three-tier partnership consisting of: (i) national government; (ii) provincial government; and (iii) the parents of the learners and the members of the community in which the school is located. ...[T]he principles that have emerged from the case law can be set out as follows: (a) Where the Schools Act empowers a governing body to determine policy in relation to a particular aspect of school functioning, a head of department or other government functionary cannot simply override the policy adopted or act contrary to it. ... But this does not mean that the school governing body's powers are unfettered, that the relevant policy is immune to intervention, or that the policy inflexibly binds other decision-makers in all circumstances. (b) Rather, a functionary may intervene in a school governing body's policy-making role or depart from a school governing body's policy, but only where that functionary is entitled to do so in terms of powers afforded to it by the Schools Act or other relevant legislation. This is an essential element of the rule of law. (c) Where it is necessary for a properly empowered functionary to intervene in a policy-making function of the governing body..., then the functionary must act reasonably and procedurally fairly. (d) Further, the co-operative governance scheme set out in the Constitution ... must be directed towards furthering the interests of learners.'

See further Head of Department, Department of Education, Free State v Welkom High School 2013 ZACC 25.

19 In deciding that the "minority" students must be accommodated, the Laerskool Middelburg court correctly concludes that the right to a single-medium public educational institution is clearly subordinate to the right which every South African has to education in a similar institution and that such institutions might require the sharing of educational facilities by different cultural communities. 
Chief Justice Moseneke's opinion also makes transparent the Court's lack of patience with Hoërskool Ermelo's intransigence with respect to language policy and to the admission of black students who wish to be taught in English:

The case arises in the context of continuing deep inequality in our educational system, a painful legacy of our apartheid history. The school system in Ermelo illustrates the disparities sharply. The learners-per-class ratios in Ermelo reveal startling disparities which point to a vast difference in resources and of the quality of education. ... [F]ormerly black public schools have been and by and large remain scantily resourced. They were deliberately funded stingily by the apartheid government. Also, they served in the main and were supported by relatively deprived black communities. That is why perhaps the most abiding and debilitating legacy of our past is an unequal distribution of skills and competencies acquired through education ... [FC s 29(2)] is made up of two distinct but mutually reinforcing parts. The first part places an obvious premium on receiving education in a public school in a language of choice [but] ... is available only when it is "reasonably practicable". ... The second part of s 29(2) of the Constitution protects the right to be taught in the language of one's choice. It is an injunction on the State to consider all reasonable educational alternatives which are not limited to, but include, single-medium institutions. In resorting to an option, such as a single or parallel or dual-medium of instruction, the State must take into account what is fair, feasible and satisfies the need to remedy the results of past racially discriminatory laws and practices. ${ }^{20}$

The Ermelo Court does not close the door on public schools that wish to order themselves along cultural or linguistic lines. However, Ermelo makes plain the proposition that the form of pluralism to which the basic law commits us is fundamentally inconsistent with a school admissions' policy that excludes a

The Laerskool Middelburg court seems to be on far shakier grounds when it suggests that a claim to a single-medium institution amounts to little more than a desire to maintain a degree of emotional, cultural, religious and social-psychological security. This reading trivializes the desire to maintain basic, constitutive attachments and the challenge that dual medium schools pose to the maintenance of order and discipline between learners (and teachers) from different cultural and linguistic communities. It seems clear that the desire to sustain a given culture as it stands is best served by single-medium institutions that reinforce implicitly and expressly the importance of sustaining the integrity of that community. Maintaining the integrity of a community has the natural consequence of maintaining order through shared mores. As a result, the Laerskool Middelburg court must be wrong when it claims that the conversion of a single-medium public institution to a dual-medium school cannot per se diminish the force of each cultural and linguistic community's claim to a school organised around its language and culture. That is exactly what the conversion does. Whether such insularity is good for learners in an open, multicultural and democratic society committed to equality, dignity and freedom is an entirely different matter. See J Jansen Knowledge in the blood: Confronting race and the apartheid past (2009). Jansen is surely correct when he contends that a failure to attempt to understand the many communities oppressed by apartheid and colonial rule will tend only to replicate the oppression in various spaces and do little to advance our commitment to a reasonably egalitarian, pluralist social order. The doors should be opened even if for no other reason than enlightened self-interest. Success in a multicultural, pluralist society now requires getting along and knowing 'the other'.

Ibid at para 58. 
significant number of students on the basis of culture or language (or race). Private ordering or group rights under our Constitution have discernible limits that flow from the commitment to pluralism itself.

\subsection{Language policy in public schools}

The new Curriculum and Assessment Policy Statement [CAPS](First Additional Language Policy) and the draft Incremental Implementation of African Language (IIAL Policy or Second Additional Language Policy (SAP)) have led to a number of disputes over the languages taught in our public schools. ${ }^{21}$ These recent policies do not merely have consequences for elite public schools which have generally chosen English and Afrikaans as primary mediums of instruction (Home Language and First Additional Language), and a third "African" language as something akin to an extracurricular activity. Prior to the introduction of CAPS, most South African schools tended to teach in their learners' home language: that is, in one or two of the nine (non-Afrikaans) African languages. ${ }^{22}$ A small percentage of disadvantaged schools shifted to English as the "default" home language and medium of instruction. In the past, most quintile 1 - 3 schools introduced English towards the end of the Foundation Phase. However, many learners in these schools did not acquire sufficient vocabulary and reading and writing proficiency to cope with the language demands of English medium teaching in Grade 4 (and beyond). ${ }^{23}$

21 Department of Basic Education (2012) National Curriculum Statement: Curriculum and Assessment Policy Statement Foundation Phase $R$-3.

22 A growing body of evidence supports the proposition that a significant percentage of learners who begin their school careers learning in one of the nine non-Afrikaans African languages is in fact not learning in their "mother tongue". Extant research reveals two permutations of this phenomenon. First, a significant portion of African language learners are taught an African language that is not spoken at home. Second, even where learners are, broadly speaking, taught in their home language, the African language of instruction often takes the form of a dialect with which they are not entirely familiar. For example, many learners speak isiMpondo rather than isiXhosa, or SeSothose-Pretoria rather than SeSotho-se-Lebowa. See National Education Evaluation and Development Unit (2013) National Report 2012.

23 Aware of this deficit, the Department of Basic Education has shifted the introduction of the first additional language to the first year of schooling. The department reasoned as follows:

Children come to school knowing their home language. They can speak it fluently, and already know several thousand words. Learning to read and write in Grade 1 builds on this foundation of oral language. Therefore, it is easier to learn to read and write in your home language. When children start to learn an additional language in Grade 1, they need to build a strong oral foundation. They need to hear lots of simple, spoken English which they can understand from the context. Listening to the teacher read stories from large illustrated books (Big Books) is a good way of doing this as it also supports children's emergent literacy development. As children's understanding grows, they need 
While CAPS may have been an appropriate curriculum policy decision for most 1 to 3 quintile schools, it has had unanticipated consequences for a growing number of quintile 5 English home language schools. Over the past fifteen years, privileged public schools such as Parkview Junior Primary in Johannesburg and Grove Primary School in Cape Town had begun teaching two additional languages in the Foundation Phase. In Johannesburg, the two additional languages tended to be Afrikaans and isiZulu. Western Cape schools were inclined to teach Afrikaans and isiXhosa. Tutelage in these additional languages was initially limited to oral instruction. By Grade 3, schools introduced a limited degree of reading and writing tuition.

A new irony arose. As a result of the new FAL requirement, a sizeable number of English first language schools (a) correctly assumed that they were obliged to make a choice as to which two languages required the "Full Monty" in the Foundation Phase and (b) opted to drop non-Afrikaans African languages and select Afrikaans as the First Additional Language. The choice of Afrikaans as the FAL was, generally, based on a range of practical considerations. First, these schools had Foundation Phase teachers that had been trained to teach Afrikaans as a second language. The African language was often taught by a specialist SGB-paid teacher. Second, the adoption of an African language as a FAL - with its additional two to three hours of weekly instruction - would have staffing consequences and increase overall school expenditure. As matters stood, these quintile 5 schools already possessed the existing resources - books and teachers - to provide instruction in Afrikaans as a second language. Few schools enjoyed comparable resources for African language instruction. Most publishers had never produced systematic materials in African languages for the youngest cohort of second language speakers. ${ }^{24}$ Third, many parents expressed anxiety regarding the extremely high demands, and disadvantage,

plenty of opportunities to speak the language in simple ways. This provides the foundation for learning to read and write in Grades 2 and 3. In South Africa, many children start using their additional language, English, as the Language of Learning and Teaching (LoLT) in Grade 4. This means that they must reach a high level of competence in English by the end of Grade 3, and they need to be able to read and write well in English. For these reasons, their progress in literacy must be accelerated in Grades 2 and 3. Id.

24 Koornhof From conception to consumption: An examination of the intellectual process of producing textbooks for foundation phase education in South Africa PhD, University of the Witwatersrand (2012). 
which IsiZulu and other African language matriculation examinations would place upon their children. Even exceptional African language students often performed poorly. Afrikaans, by contrast, was widely viewed as an "easy" language that offered the opportunity for excellent matric results. For learners in elite public schools competing for a limited number of places in first rate university programmes, a mediocre FAL mark could well prejudice their chances. Given the "locked-in" systemic advantages of tuition in English and Afrikaans, the SGBs of many top quintile schools chose Afrikaans as the FAL and dropped African language instruction. The irony of which Deputy Chief Justice spoke is no longer collateral. ${ }^{25}$ Diminished African language instruction, in a growing cohort of schools, is a direct function of the absence of adequate teaching materials, qualified teachers, additional expenses, ostensibly difficult matric exams, and the lock-in of English and Afrikaans as dominant languages of instruction. ${ }^{26}$

Both the Ermelo Court and the national government have made it clear that the 9 official African languages ought to be treated with the same degree of respect accorded Afrikaans and English. ${ }^{27}$ For sound pedagogical reasons, they want to ensure that home language instruction and second language tuition are offered from initial entrance into our primary schools. Moreover, both the Ermelo Court and the national government have recognised that schools not only have an obligation to provide what learners believe to be appropriate and desired instruction in the languages of their choice, but they also have an obligation to prepare learners, through language instruction, with the capacity to engage various members of South Africa's pluralist polity -- who do not share their home language -- in a respectful and dignified fashion. However, the problem identified above with respect to the space schools are granted for maintaining a balance between institutional order and cultural autonomy is replicated here. To ensure sufficient order so that effective learning can take place, the state and all other concerned parties must guarantee the

25 Smit "Collateral irony" and "insular construction": Justifying single medium schools, equal access and quality education' (2011) 27 South African Journal on Human Rights 398.

26 It is accurate to say that (a) almost all former Model C schools in Gauteng (including schools with a majority of black learners), and (b) virtually all schools in Gauteng with English, Afrikaans, Indian and Coloured learner majorities have opted for Afrikaans and English language instruction. The LOLTS survey is but one public source of this data.

27 Woolman \& Fleisch "The Problem of the 'Other' Language" (2014) 5 Constitutional Court Review 183. 
availability of appropriately trained teachers and administrators, as well as the adequacy of existing textbooks, across all 11 languages. The new policies recognise cognisable, constitutionally-recognised limits on each school's capacity to deliver immediately upon this laudable goal and commitment to pluralism.

\subsection{Private ordering and public schools}

The constitutional matter in Governing Body of the Juma Musjid Primary School v Ahmed Asruff Essay arose out of a dispute between the Juma Musjid Trust (Trust), the owner of the private property, the Member of the Executive Council for Education for KwaZulu-Natal (MEC), the School Governing Body (SGB) for Juma Musjid Primary School, and the learners and parents at the school. ${ }^{28}$ The trust, a private entity, had for some time leased the land to the government. The government had, in turn, used the property for maintaining a primary school. The dispute arose when the Trust and the MEC of Education for KwaZulu-Natal could not conclude an agreement under the South African Schools Act regarding continued tenancy by the province and the school. The Trust then secured an eviction order in the High Court. The Supreme Court of Appeal upheld the order. Unlike the courts below, the Constitutional Court was not so ready to allow private interests to trump public interests. The Court framed the discussions to be had by all the concerned parties within the following normative rubric. First, the Trustees had a negative duty in terms of $s 8(2)$ and $s$ 29(1) of the Constitution not to infringe the right of the learners to access to a basic education. Second, while the trustees had acted reasonably in approaching the High Court for an eviction order, its behaviour did not constitute sufficient reason for the High Court to grant the eviction order under the circumstances. The trustees and the High Court had failed to consider properly the best interests of the learners and their right to a basic education. Third, the MEC had a positive obligation to provide access to schools in line with the learners' right to a basic education, and had thus far failed to discharge that duty. Fourth, if meaningful engagement between the parties failed, then the MEC was obliged to take steps to secure alternative placements for the learners. In addition, the MEC was required to file a report setting

28 Governing Body of the Juma Musjid Primary School v Ahmed Asruff Essay [2011] ZACC 13, 2011 (8) BCLR 761 (CC). 
out, among other things, the steps that she had taken to ensure that the learners' right to a basic education had been secured. The Constitutional Court asked the parties to reach a normatively satisfying and Pareto-optimal settlement in light of the Court's gloss on the constitutional rights and common-law obligations of the parties.

The parties could not meet the Court's desiderata. The result, in the end, was castigation of each and every party to the dispute (save for the learners) and a court order that tracked the content of the original meaningful engagement order (as delineated above). ${ }^{29}$

For my purposes, the most compelling feature of the judgment is the Court's recognition that private actors have predominantly negative obligations regarding the basic education of learners at primary and secondary public schools. The Juma Musjid Court's path-breaking finding is that a private party - the Trust - clearly had a negative duty in terms of $s$ 29(1) of the Constitution not to impair the access of learners to public schools. How this judgment serves the ends of pluralism requires some teasing out.

The private trust was clearly interested in using the land and the school for sectarian purposes. That is, they wished to take the school out of the orbit of the public school system. Juma Musjid thus offers rather penetrating insight as to (a) how private parties will be treated with respect to their contributions to, or their interference with, learners' rights to a basic education; (b) the extent to which private parties may use their wealth and their power to determine the ethical and cultural ethos of a school; and (c) the circumstances in which the constitutional commitment to pluralism trumps sectarian interests.

The Juma Musjid Court clearly echoes the Gauteng School Education Bill Court's distinction between the pursuit of a specific religious, cultural or linguistic ethos in public schools and in private schools. The Constitutional Court - in both cases -

29 For a rather optimistic account of the trajectory of the Court's meaningful engagement jurisprudence, see Woolman The Selfless Constitution: Experimentation and Flourishing as Foundations of South Africa's Basic Law (2013). For a more sceptical reading, see McLean 'Meaningful engagement: One step forward or two steps back? Some thoughts on Joe Slovo' (2011) 3 Constitutional Court Review 223. 
limits the degree to which public schools can be used to advance the religious, cultural or linguistic interests of learners from one subpublic at the expense of learners from another subpublic. Private religious, cultural or language based schools retain a significant degree of space within which to create a room of and for their own.

Juma Musjid also resonates profoundly with debate surrounding school fees (a matter that has never reached the Constitutional Court because of legislative interventions. $)^{30}$ Despite cries for a no-fee education system across the board, the state correctly disaggregated Quintile 1 schools through Quintile 3 schools from Quintile 4 and Quintile 5 schools. By allowing the two highest quintiles to continue to charge fees, the state clearly acknowledged that private parties - whether natural persons or juristic persons - could substantially alter the form and the substance of an individual school through their contributions to its purse. It's fair to say that the Constitution contemplates this arrangement by not requiring basic education to be free under s 29(1) of the Constitution: -- thereby encouraging various religious, cultural and linguistic groups to seek accommodation within public schools in terms of $s$ 29(2) of the Constitution.

If we are to take seriously the horizontal application of s 29(1) to private parties, as well as the Constitution's commitment to pluralism, then we must contemplate the possibility that the contributions and therefore the influence of natural persons or juristic persons over the manner in which a school is ordered will be subject to an obligation not to interfere with the rights of learners to a basic education. So, for example, if a large number of isizulu-speaking parents, or an organisation devoted to the promotion of Zulu culture, made significant contributions by way of the lease of private property or donations of increased fees to a given school so that both the language and the culture would be given prominence of place, the learning from Juma Musjid (and Ermelo) is that such a school could not negatively interfere with rights of a significant cohort of other learners to be admitted to the school or to receive tuition in their first language of choice. Once again: the Court has quietly

30 Woolman \& Fleisch "On the constitutionality of school fees: A reply to Roithmayr" (2004) Perspectives in Education 111 - 123. 
reached into the internal affairs of individual public schools and found that sectarian interests cannot ride roughshod over the commitment to pluralism reflected in the Constitution. And again: the partition between what private parties may do in public schools and what they may do in private schools is on all fours with the holding in Gauteng School Education Bill. If parents wish to have the internal affairs of a school strictly governed by the dictates of a particular religion, the practices of a specific culture, or the tuition in a specific language, then they are free to do so in terms of $\mathrm{s}$ 29(3) of the Constitution and through the formation of an independent school (that still may not discriminate on racial grounds).

\section{$3 \quad$ Pluralism and order in our public schools}

\subsection{Habermas and the golden thread}

What exactly does Habermas mean when he states that "[t]he development of constitutional democracy along the celebrated 'North Atlantic' path has certainly provided us with results worth preserving, but once those who do not have the good fortune to be the heirs of the Founding Fathers turn to their own traditions, they cannot find criteria and reasons that would allow them to distinguish what would be worth preserving from what should be rejected"? He means that the constitutions (written and unwritten) of older, well-established democracies are grounded in traditions that can readily identify the normative content that ought to fill out the basic law. Every reader knows that the constitutional democracies of the celebrated "North Atlantic" to which Habermas refers in 1996 encompassed no more than a fistful of nations. His worry and his focus then shifts to those nations that, after the fall of the Berlin Wall in 1989, felt themselves obliged to reconstruct themselves, at least formally, along the lines and through documents that parroted the language of celebrated "North Atlantic" constitutions and of covenants generated by the United Nations. In these new constitutional orders, the basic law came not from the ground up (as a reflection of shared political, social, cultural, religious and economic traditions) but from the top down. These new Constitutions were largely drawn up by sophisticated (legally-trained) elites (and a large number of foreign experts) whose immediate concerns were not an adequate reflection of the multiplicity of 
traditions and communities that made up the polity. For these more traditional associations, communities, bonding networks and subpublics, the new constitution was just another illegitimate imposition - albeit something of an improvement upon the authoritarian, communist or racist regimes from which they had been liberated. In this regard, Habermas was a decade (or two) ahead of comparative constitutional law scholars cum political scientists who (suddenly) have discovered that a large portion of the post-1989 constitutional democracies have become one-party dominant democracies plagued by the three Cs of cronyism, clientelism and corruption. ${ }^{31}$

Habermas' prescience lay in two critical insights into the celebrated "North Atlantic" constitutional democracies and the new constitutional democracies arriving on the scene as he began this seminal work in the late 1980s. First, constitutions are scaffolding: they require social, cultural and economic arrangements within which the hurly-burly of politics can be worked out in a manner that satisfies the demands for meaningful collective action. Second, to be successful, constitutional democracies require: (a) a robust civil society which not only mediates vertical relationships between citizen and state, but also facilitates, negotiates and resolves horizontal relationships between citizens, and between the various associations that provide the setting for the lion's share of meaningful action undertaken by individuals within the polity itself; 32 (b) a commitment to the rule of law that, at a minimum, ensures that the governed and the governors are subject to the same legal strictures, and

31 Choudhry "'He had a Mandate": The South African Constitutional Court and the African National Congress in a dominant party democracy' (2009) 2 Constitutional Court Review 1; Choudhry Constitutional design for divided societies: Integration or accommodation (2008); Roux "The South African Constitutional Court's democratic rights jurisprudence" (2014) 5 Constitutional Court Review 33; Roux The politics of principle: The first South African Constitutional Court, 1995 - 2005 (2013); Roux "Principle and pragmatism on the Constitutional Court of South Africa" (2009) 7 International Journal of Constitutional Law 106; Issacharoff "Constitutional Courts and Democratic Hedging" (2012) 99 Georgetown Law Journal 961; S Issacharoff "Constitutionalizing democracy in fractured societies" (2004) 82 Texas Law Review 1861; Issacharoff "The democratic risk to democratic transitions" (2014) 5 Constitutional Court Review 1; Dixon \& Ginsburg "The South African Constitutional Court and socio-economic rights as insurance swaps" (2012) 4 Constitutional Court Review 1; Klug "Finding The Constitutional Court's place in South Africa's democracy: The interaction of principle and institutional pragmatism in the court's decision-making" (2010) 3 Constitutional Court Review 1; Klug The Constitution of South Africa: A Contextual Analysis (2010).

32 Krygier "The quality of civility: Post-Anti-Communist thoughts on civil society and the rule of law" in Sajó (ed) Out of and into authoritarian law (2002) 55. 
ultimately (c) a commitment to the rule of law that maximally enhances the mutual concern, respect and trust that individuals (and groups) have for one another and which enables them to cooperate in a manner that does not require coercion by the state in order to produce public goods on scale. ${ }^{33}$

With respect to the first insight, the South African Constitutional Court quickly recognised that its role was to provide "scaffolding". Such is the learning of the First Certification Judgment. ${ }^{34}$ What the Constitutional Court could not do, and no apex court ever does do, was to recast the socio-economic environment that it had inherited in a manner that generated (rather immediately) the social democratic outcomes (or at least the liberal democratic outcomes) identified with its celebrated predecessors. One does not jump from an oppressive political order with the world's highest Gini-coefficient to a social democracy simply by having one of the most cleverly designed constitutions in history. With respect to the second insight, the Court did what it could. It placed at the centre of its project the (a) creation of a rule of law culture; (b) the promotion of individual rights that quite often led to the reversal of colonial and apartheid-era rules of law; (c) enhanced roles for public participation in the legislative process and (d) greater insulation from political interference for the Office of the Public Protector, the Auditor-General, and to whatever other 'independent' investigatory unit is charged with rooting out corruption. ${ }^{35}$

The Constitutional Court also recognised something critical for our nascent constitutional democratic project. It shares Habermas' insight that the radical heterogeneity of the communities, subpublics, cultural networks and associations that fall with South Africa's sovereign borders (and likewise reflect our oppressive history of so-called separate development) leave the Court in a position where it cannot easily draw down on any one tradition to decide what aspects of our society we should preserve and what aspects of our society we should discard. Until such

\footnotetext{
33 Olson The logic of collective action: Public goods and the theory of groups (1965).

34 Ex Parte Chairperson of the Constitutional Assembly: In Re Certification of the Constitution of the Republic of South Africa, 199619964 SA 744 (CC), 199610 BCLR 1253 (CC).

35 Glenister v President of the Republic of South Africa. 2011 ZACC 6, 20113 SA 347 (CC), 20117 BCLR 651 (CC).
} 
time that we can adequately stitch together our component parts, a commitment to pluralism - political, legal, social, religious, cultural and linguistic - remains the most defensible justification available to the Court in the kinds of cases canvassed herein.

\subsection{The golden thread of pluralism in the Constitutional Court's education jurisprudence}

The recognition of pluralism - the unavoidability of pluralism - is the Court's golden thematic thread. It runs through cases as "diverse" as Prince, Bhe and Fourie. It explains our modest body of education jurisprudence, and, consequently, the manner in which schools may order their admissions policies, curriculum and other internal affairs, whilst adequately recognising learners' rights. Pluralism underwrites Justice Kriegler's assessment - in Gauteng Education Bill - of the limits placed upon what a public school may do with regard to a learner's rights to religion, culture and language and the greater degree of latitude afforded independent schools with regard to such matters. Pluralism grounds Justice Sach's distinction - in Christian Education - between the form of discipline that may be used by a teacher upon a learner in a "public" setting (irrespective of the religious tenets by which the school abides) and the form of chastisement that parents may employ at home (in a manner consistent with the strictures of their religious faith.) Pluralism does virtually all the heavy lifting in Justice Langa's opinion in Pillay. It places the burden on school officials to demonstrate why the granting of an exemption to a learner regarding religious or cultural dress should be subordinate to a disciplinary code that governs the garb worn by other learners within a school. Pluralism provides the foundations for Justice Moseneke's dual contention - in Ermelo -- that (a) language policies cannot be used to bar from admission a significant cohort of learners who seek tuition in a language of their choice and (b) language policies, going forward, must take into account the equal standing of all 11 official languages and provide the curriculum and the resources necessary for speakers of these 11 official languages to meet one another as equals in the public square. Consistent with Justice Moseneke's findings in Ermelo, pluralism provides the justification for the state's First Additional Language Policy and the Incremental Implementation of African Languages Policy. Pluralism lies at the core of Justice Cameron's argument - in Juma Musjid -- that a 
learner's right to a basic education cannot be undermined by a private party's desire to advance the narrow, sectarian interests of a given religious community.

\subsection{The effect of pluralism on membership and governance in public schools}

Taken as a whole, what effect does the Court's commitment to pluralism in its education judgments have on the manner in which our classrooms are constructed? In the absence of a single tradition from which learners' rights can be drawn, the Constitutional Court has adopted an "open the door" approach. Learners who wish to receive tuition in an official language of their choice must, where it is reasonably practicable to do so, be accommodated. Nor are the majority of learners denied the right to receive tuition in their preferred tongue. Of course, this "open the door" approach places additional burdens on school officials. They must learn to accommodate "differences" - especially differences that have long been repressed. They must enable learners from a multiplicity of traditions to live with and study with one another. In a nation long governed by apartness, this golden thread of pluralism provides us with an opportunity to do things differently - whether in terms of tuition in a language other than Afrikaans or English, or preventing private parties from using state run schools to advance sectarian interests. The Court is simply opening the door to learners for whom the door has historically been closed.

Will white kids continue to sit with white kids, black kids with black kids, and Indian kids with Indian kids? Of course. Pluralism accommodates cliques. We find comfort in what's common. We seek out succour and solace in what might appear to be a dull sameness. Nowhere, whether in Habermas' Between Facts and Norms, in Judt's ruminations on Belgium, or in the learning to be had from our Constitutional Court, does it say we must all be friends. The Court's commitment to pluralism simply opens public school doors to all learners. The burden that falls on school governing bodies, principals, teachers and other schools officials is to keep them open and create something greater than the sum of the parts of our radically heterogeneous South Africa. 


\section{BIBLIOGRAPHY}

\section{Literature}

Choudhry Migration of Constitutional Ideas

Choudhry S The Migration of Constitutional Ideas (Cambridge University Press Cambridge 2006)

Choudhry Constitutional Design

Choudhry S Constitutional Design for Divided Societies: Integration or Accommodation (Oxford University Press Oxford 2008)

Choudhry 2009 CCR

Choudhry S "'He had a Mandate': Constitutionalism in a Dominant Party Democracy" 2009 CCR 1

DBE National Curriculum Statement

Department of Basic Education National Curriculum Statement: Curriculum and Assessment Policy Statement Foundation Phase R-3 (The Department Pretoria 2012)

Dixon and Ginsburg 2012 CCR

Dixon R and Ginsburg T "The South African Constitutional Court and Socioeconomic Rights as Insurance Swaps" 2012 CCR 1-29

Habermas Between Facts and Norms

Habermas J Between Facts and Norms: Contributions to a Discourse Theory of Law and Democracy (MIT Press Cambridge MA 1996)

Issacharoff 2004 Tex $L$ Rev

Issacharoff S "Constitutionalizing Democracy in Fractured Societies" 2004 Tex L Rev 1861-1893

Issacharoff 2012 Geo LJ

Issacharoff S "Constitutional Courts and Democratic Hedging" 2012 Geo LJ 961-1012 
Issacharoff 2014 CCR

Issacharoff S "The Democratic Risk to Democratic Transitions" 2014 CCR 1-32

Jansen Knowledge in the Blood

Jansen JD Knowledge in the Blood: Confronting Race and the Apartheid Past (Stanford University Press Stanford CA 2009)

Klug Constitution of South Africa

Klug H The Constitution of South Africa: A Contextual Analysis (Hart Oxford 2010)

Klug 2010 CCR

Klug $\mathrm{H}$ "Finding the Constitutional Court's Place in South Africa's Democracy:

The Interaction of Principle and Institutional Pragmatism in the Court's Decision-making" 2010 CCR 1-32

Koornhof From Conception to Consumption

Koornhof $\mathrm{H}$ From Conception to Consumption: An Examination of the Intellectual Process of Producing Textbooks for Foundation Phase Education in South Africa (PhD-thesis University of the Witwatersrand 2012)

Krygier "Quality of Civility"

Krygier M "The Quality of Civility: Post-Anti-Communist Thoughts on Civil Society and the Rule of Law" in Sajó A (ed) Out of and Into Authoritarian Law (Kluwer Law International The Hague 2002) 221-256

McLean 2011 CCR

McLean K "Meaningful Engagement: One Step Forward or Two Steps Back?

Some Thoughts on Joe Slovo" 2011 CCR 223-242

NEEDU National Report 2012

National Education Evaluation and Development Unit, Department of Basic Education National Report 2012 (The Department Pretoria 2013) 
Olson Logic of Collective Action

Olson M The Logic of Collective Action: Public Goods and the Theory of Groups (Harvard University Press Cambridge MA 1965)

Roux 2009 ICON

Roux T "Principle and Pragmatism on the Constitutional Court of South Africa" 2009 ICON 106-138

Roux Politics of Principle

Roux T The Politics of Principle: The First South African Constitutional Court, 1995-2005 (Cambridge University Press Cambridge 2013)

Roux 2014 CCR

Roux T "The South African Constitutional Court's Democratic Rights Jurisprudence" 2014 CCR 33-73

Smit 2011 SAJHR

Smit MH '"Collateral Irony' and 'Insular Construction': Justifying Single Medium Schools, Equal Access and Quality Education" 2011 SAJHR 398-433

Sunstein One Case at a Time

Sunstein CR One Case at a Time: Judicial Minimalism on the Supreme Court (Harvard University Press Cambridge MA 1996)

Woolman 2007 Stell LR

Woolman S "Defending Discrimination: On the Constitutionality of independent Schools that Promote a Partial, if not a Comprehensive, Vision of the Good" 2007 Stell LR 31-52

Woolman Selfless Constitution

Woolman S The Selfless Constitution: Experimentation and Flourishing as Foundations of South Africa's Basic Law (Juta Cape Town 2013)

Woolman and Bishop "Education"

Woolman S and Bishop M "Education" in Woolman S and Bishop M (eds) Constitutional Law of South Africa $2^{\text {nd }}$ ed (Juta Cape Town 2008) ch 58 
Woolman and Fleisch 2004 Perspectives in Education

Woolman S and Fleisch B "On the Constitutionality of School Fees: A Reply to Roithmayr" 2004 Perspectives in Education 111-123

Woolman and Fleisch Constitution in the Classroom

Woolman S and Fleisch B The Constitution in the Classroom: Education and the Law in South Africa, 1994-2008 (PULP Pretoria 2009)

Woolman and Fleisch 2014 CCR

Woolman S and Fleisch B "The Problem of the 'Other' Language" 2014 CCR $135-172$

\section{Case law}

Antonie v Governing Body, Settlers High School 20024 SA 738 (C)

Bhe v Magistrate, Khayelitsha 20051 SA 580 (CC)

Christian Education South Africa v Minister of Education 20004 SA 757 (CC)

Ex Parte Chairperson of the Constitutional Assembly: In Re Certification of the Constitution of the Republic of South Africa, 199619964 SA 744 (CC)

Ex Parte Gauteng Provincial Legislature: In Re Dispute Concerning the Constitutionality of Certain Provisions of the Gauteng School Education Bill of 199519963 SA 165 (CC)

Glenister $v$ President of the RSA 20113 SA 347 (CC)

Governing Body, Mikro Primary School v Minister of Education, Western Cape 20053

SA 504 (C)

Head of Department, Department of Education, Free State Province v Welkom High Schoo/ 20142 SA 228 (CC)

Head of Department, Mpumalanga Department of Education v Hoërskool Ermelo 20102 SA 415 (CC)

KwaZulu-Natal MEC for Education v Pillay 20081 SA 474 (CC)

Laerskool Middelburg v Departementshoof, Mpumalanga Departement van Onderwys 20034 SA 160 (T)

Matukane v Laerskool Potgietersrus 19963 SA 223 (T) 
Member of the Executive Council for Education in Gauteng Province $v$ Governing Body of the Rivonia Primary School 20136 SA 582 (CC)

Minister of Home Affairs v Fourie 20061 SA 524 (CC)

Prince v President, Cape Law Society 20022 SA 794 (CC)

S v Williams 19953 SA 632 (CC), 19957 BCLR (CC)

Seodin Primary School v MEC Education, Northern Cape 20061 All SA 154 (NC)

\section{Legislation}

Children's Act 53 of 2005

Constitution of the Republic of South Africa Act 200 of 1993 (Interim Constitution) Constitution of the Republic of South Africa, 1996

South African Schools Act 84 of 1996

\section{LIST OF ABBREVIATIONS}

CAPS

CCR

DBE

FAL

Geo LJ

ICON

IIAL Policy

LoLT

MEC

NEEDU

SAJHR

SAP

SGB

Stell LR

Tex L Rev

Tulsa L Rev
Curriculum and Assessment Policy Statement

Constitutional Court Review

Department of Basic Education

First Additional Language

Georgetown Law Journal

International Journal of Constitutional Law

Incremental Implementation of African Language Policy

Language of Learning and Teaching

Member of the Executive Council

National Education Evaluation and Development Unit

South African Journal on Human Rights

Second Additional Language Policy

School Governing Body

Stellenbosch Law Review

Texas Law Review

Tulsa Law Review 